\title{
Eu fofoco? Tu fofocas? As paixões em redes de intrigas
}

\author{
Carla Moreira de Paula Prada \\ Luisiana Ferreira Moura
}

N ós fofocamos. Falar mal de alguém é uma prática que não poupa ninguém. maneira até inconsciente. Bradamos que não somos fofoqueiros, afinal não é um hábito louvável, mas quando menos esperamos, enunciamos a outro um juízo sobre alguém. Podemos dizer que apenas opinamos, no entanto, se erguemos um juízo negativo explícito ou subentendido sobre alguém ou sobre a atitude de alguém, sem que nos diga respeito, a fofoca é instaurada.

A fofoca é democrática, não restringe classe, instância ou esfera. Da fofoca comezinha, ligada a cuidar das idas e vindas dos vizinhos, à fofoca de Estado, que incide sobre questões políticas e econômicas, os valores e as paixões (emoções) são pátina ${ }^{1}$ que reveste o fato e impulsiona uma verdade contingente. Orientado a um propósito, o detrator atua com base em uma seleção própria de valores que problematiza, para reafirmar ou contestar, a fim de agir sobre a vontade do outro. Para isso, procura movimentar as paixões de seu auditório para que ele comungue de sua verdade em relação ao detratado. Esta verdade não é absoluta, é verossímil, pois atende àquilo que o detrator pretende alcançar com o seu discurso fofoqueiro. O discurso pode ser reproduzido e propagar-se de tal modo que, entre o fato e o que é reproduzido, há tantas camadas de pátina que apenas se mantém uma pequena ideia da origem e do fato.

1 Camada esverdeada que se forma sobre o cobre ou o bronze quando expostos por muito tempo à ação do tempo e do ar; 2. Oxidação das tintas pela ação do tempo e sua transformação gradual pela luz; 3 . Depósitos terrosos que se formam sobre a superfície dos mármores antigos; 4 . Pintura decorativa que procura reproduzir esses efeitos de envelhecimento em objetos e móveis (AULETE, Caldas. Novíssimo Aulete: dicionário contemporâneo da língua portuguesa. Organização de Paulo Geiger. Rio de janeiro: Lexikon, 2011, p. 1036) 
As paixões movimentadas nesse contexto discursivo constituem uma trama. Nela se entrecruzam não só as emoções do auditório, mas também as do orador, pois estão na base motivadora do seu ato detrator e, a depender de como a rede de intrigas se ergue, as do próprio detratado com sua percepção sobre aquilo que vivencia e com a urgência em estabelecer limites para a pátina acumulada. É delineada, assim, uma comunhão de paixões que, conforme perspectiva cartesiana, afeta não só o auditório, mas também o orador e qualquer um que seja envolvido na tessitura dessa trama.

As paixões, portanto, sobressaem-se nos atos de detração e atingem todos os agentes envolvidos no contexto de fofoca. Com base nessas premissas, buscamos identificar as paixões e os efeitos compartilhados nessa prática, subproduto da humanidade. Para isso, selecionamos uma carta do diplomata barão de Mareschal à corte austríaca e fragmentos de cartas da imperatriz D. Leopoldina à irmã, sobre seu relacionamento com D. Pedro e o envolvimento deste com a Marquesa de Santos. Também, estabelecemos o diálogo entre a Retórica e o pensamento cartesiano acerca das paixões, além de confirmar a proeminência do pathos, em relação às outras provas retóricas - o ethos e o logos.

O diálogo constrói-se com base na perspectiva fisiológica proposta por Descartes (2012) de que a paixão é uma ação sobre o corpo do sujeito a quem acontece (auditório), mas também ação naquele que a provoca (orador). A fofoca favorece esse duplo movimento porque compreende relações de poder e cristaliza identidades. ${ }^{2}$ Muitas vezes, é uma arma contra o outro, pois transita dentro de hierarquias de valores, as quais procura reafirmar ou reorganizar, de acordo com as motivações de seu produtor.

\section{Descartes e Aristóteles: acerca das paixões.}

A Retórica é uma ciência que se fundamenta em três provas retóricas: o ethos, o pathos e o logos. Cada prova possui sua importância, contudo, de acordo com o ato retórico e as intenções do orador, pode haver maior investimento em uma ou outra. Assim como o ethos, o pathos é o argumento de ordem psicológica vinculado à afetividade porque remete às emoções e paixões que se deseja despertar no outro. Por meio dele, o orador atua sobre a hierarquia de valores do auditório em busca de adesão pela criação de vínculos e, no lugar de convencer pela razão, investe na alteração do estado de alma de sua audiência

2 Karnal, 2016 
para comover e seduzir pelo coração. ${ }^{3} \mathrm{Na}$ concepção aristotélica, portanto, as paixões são recursos efetivos porque, quando orientadas aos propósitos persuasivos, por meio da ação do orador, fazem as pessoas mudar seus pensamentos e, por conseguinte, seus julgamentos.

As três provas retóricas são abordadas nas ciências humanas. Curiosamente, Descartes (2012), na apresentação da obra As paixões da alma, afirma que não a escreveu como filósofo moral, mas somente como físico. Nessa posição e de acordo com a concepção fisiológica, diferenciou, antes de tudo, corpo e alma: o calor e o movimento procedem do corpo; à alma pertencem os pensamentos, divididos em dois gêneros: ações da alma e paixões.

Aqueles que designo como suas ações [da alma] são todas as nossas vontades, porque sentimos que vêm diretamente de nossa alma e parecem depender exclusivamente dela. De igual modo e ao contrário, pode-se em geral designar suas paixões todas as espécies de percepções ou conhecimentos existentes em nós (...). ${ }^{4}$

Segundo Aristóteles (2000), as paixões movimentam a alma de tal maneira que exercem uma função intelectual epistêmica. Meyer (2000), ao explicar as concepções aristotélicas, conclui que as paixões operam como imagens mentais e estabelecem como alguém age sobre o outro e como se dá a reação. Já para Descartes (2012), considerar a alma e as paixões como potentes para movimentar o corpo é um erro, que implica na falta de explicação sobre as paixões. Entende as paixões como emoções da alma, alimentadas por processos fisiológicos que preparam o corpo para agir. Assim, segundo o físico, o que na alma é uma paixão, no corpo é uma ação, impulsionada sobretudo pela vontade.

O principal efeito de todas as paixões nos homens é que elas incitam e dispõem sua alma a querer as coisas para as quais elas preparam seus corpos, de modo que o sentimento do medo a incita a fugir, aquele da audácia a querer combater, e assim também em relação aos outros. (...) Toda ação da alma consiste em, pelo simples fato de querer alguma coisa, fazer com que a pequena glândula, à qual está estreitamente unida, se mova de forma que é exigida para produzir o efeito que se relaciona com essa vontade. ${ }^{5}$

Tringali, 2014 
Em resumo, as paixões incitam a alma a preparar o corpo para agir. Nessa perspectiva, são percepções que desencadeiam o processo fisiológico que impulsiona as ações, logo, a ação não depende das paixões, mas de processos físicos do corpo.

A diferença de percepção acerca das paixões está diretamente relacionada a abordagem e área científica da qual partem os dois teóricos: a Filosofia e a Física. Concordam que as paixões exercem influência sobre o sujeito e são responsáveis por transformações que o levam a agir. No entanto, Aristóteles defende que incide sobre a alma e pode alterar as percepções do sujeito e mudar seus julgamentos, enquanto, para Descartes, incidem sobre a vontade e levam a alma a preparar o corpo para agir. A concepção cartesiana, portanto, afasta-se do conceito de que o fenômeno é paixão "em relação ao sujeito em quem acontece e uma ação em relação àquele que faz com que aconteça", ${ }^{6}$ em razão de defender que atinge ambos sujeitos de maneira similar. Não obstante as diferentes perspectivas, é uma prova de grande potência persuasiva, porque leva o indivíduo a agir.

\section{A fofoca e o movimento das paixões}

Com base na premissa de que as paixões têm como primazia movimentar o sujeito e que o contexto de fofoca ergue-se num contínuo de emoções e paixões em tensão, concordamos que o orador ao mesmo tempo em que incita as paixões ao produzir uma fofoca, foi anteriormente motivado por um conjunto de emoções que impulsionaram sua vontade. Ao fofocar, o orador está imerso em dois movimentos passionais: as alterações fisiológicas descritas por Descartes (2012) e processos cognitivos defendidos por Aristóteles (2000).

Segundo Karnal, "a fofoca anda de mãos dadas com a cobiça e a inveja,", ou seja, o fofoqueiro para produzir o discurso é motivado por essas paixões. Natural imaginar que a maioria das pessoas desejariam para si os privilégios e poder de um imperador, entretanto, dependendo do contexto retórico do discurso, outras paixões também impulsionam o ato retórico, como a indignação e a admiração, paixões centrais no discurso analisado.

Figueiredo (2018), baseada na pesquisa de Trueba Atienza (2009), defende que quando um sentimento de dor ou prazer é desencadeado no sujeito, faz com que este crie significações cognitivas - sensações ou percepções. A partir desse processo o corpo sofre alterações passionais que "geram os desejos ou impulsos

Ibid., p. 32

Karnal, 2016, s/n 
que remetem ao movimento/ação daquele sujeito em relação a problemática que alterou seu campo emocional em um nível psicofísico".

Assim, para elucidar a trajetória das paixões, Figueiredo (2018) baseou-se nas concepções aristotélicas acrescidas das de Trueba Atienza (2009) que também considera as questões fisiológicas do processo. A autora apresenta cinco etapas constituintes da trajetória: disponibilidade, identificação, alteração psicofísica, mudança de julgamento e a ação. Com base nessa trajetória, observamos como o produtor da fofoca se torna orador e incita seu auditório.

A primeira etapa, da disponibilidade, refere-se à aceitação e à disposição emocional do auditório. Ao elaborar um discurso persuasivo, o orador procura incitar as emoções de seu auditório, mas para isso é necessário que o auditório esteja disponível afetivamente para disponibilizar um espaço no qual o orador trabalha em seu ato argumentativo. Quando a disponibilidade se faz presente de maneira bem sucedida a "trajetória das paixões recebe o aval para percorrer de forma imbatível a máquina humana".

O segundo estágio é a identificação, por meio dela são acionados os processos cognitivos geradores das sensações ou percepções e das impressões racionais. Nesse momento as paixões exercem sua função epistêmica, mas só ocorre a identificação com a causa e a verdade do orador se o auditório se sensibilizar.

Essas duas etapas constituem-se na perspectiva aristotélica de que a paixão incita a alma e altera o julgamento. Ambas são concretizadas no campo cognitivo: a disponibilidade em ouvir e a consequência de se identificar. Analisar o detrator por esse viés é compreender que ele está inserido em um contexto retórico e de certa forma submetido ao seu próprio discurso como resultado das paixões que o levou a agir.

A terceira fase é a alteração psicofísica, nesse momento os processos fisiológicos são evidenciados. As paixões deixam de exercer somente a função intelectual e atingem "o corpo, e o interpela, e o conduz, juntamente com a mente, a uma mudança de julgamento". ${ }^{10}$

Após a alteração fisiológica, instaura-se na quarta etapa a mudança de julgamento, momento da conjunção do corpo e da mente. Ambos sãos instigados pela mudança de julgamento e o auditório é convocado para a ação.

Por último, na etapa de ação, o auditório é conduzido a agir; propósito fundamental para um discurso persuasivo, levar o auditório a fazer. As três últimas etapas evidenciam o quanto as reações fisiológicas apresentadas por Figueiredo (2018) e defendidas por Descartes (2012) fazem parte da constituição do

8 Figueiredo, 2018, p. 149

9 Ibid., p. 154

10 Ibid., p. 156 
discurso persuasivo. Nesse sentido, o detrator faz parte de um ato retórico no qual foi estimulado pela função epistêmica das paixões e instigado pelos processos fisiológicos que as constituem. Logo, produz discursos que espelham as paixões em movimento em si, reveladoras e motivadoras da sua posição diante da questão retórica, para a qual procura adesão.

\section{Paixão, desencanto e fofoca protagonizam no contexto retórico}

A Retórica parte do pressuposto que cada um age segundo convicções que podem ser alteradas por meio da argumentação. Voltado a esse objetivo, o orador atua no universo da doxa, abrigo de referências e opiniões em tensão, com o propósito de influenciar o auditório e conseguir adesão. Assim, orienta a construção discursiva com vistas a persuadir o outro para que, diante de uma questão, tome o seu partido e aceite a sua verdade. Isso é possível pela articulação de meios racionais e afetivos dentro do contexto retórico que emoldura o ato retórico e seus três elementos: orador, auditório e discurso.

A persuasão não prescinde, pois, do "conjunto de fatores temporais, históricos, culturais, sociais etc., que exercem influência no ato de produção e de recepção dos discursos" ${ }^{11}$ porque eles são fatores determinantes para a produção e na recepção do discurso. Portanto, para maior compreensão dos recursos afetivos e das estratégias retóricas articuladas no discurso analisado, é necessário reconstruir o contexto retórico no qual as paixões se entrecruzam.

O casamento entre D. Pedro I, príncipe herdeiro do trono português, e D. Leopoldina, arquiduquesa da Áustria, oficializado em Viena no ano de 1817, atendia a duplo interesse, como é comum em todo casamento dinástico. Fazer com que a corte portuguesa estabelecida no Brasil desde 1808 tivesse maior influência diplomática na Europa e garantir ao Império austríaco a oportunidade de firmar contratos econômicos vantajosos. Embora ciosa dos deveres políticos e econômicos relacionados ao seu casamento, D. Leopoldina revelou em cartas à irmã Maria Luíza, certa disposição romântica: "o retrato do príncipe está me deixando transtornada, é tão lindo como um adonis (...) já estou completamente apaixonada, o que será de mim quando vir o príncipe todos os dias?"12 
A arquiduquesa fora criada dentro de princípios muito rígidos: "É preciso inspirar-lhes (aos filhos) a única paixão que devem fomentar, isto é, a da humanidade, da compaixão e da ânsia de fazer a felicidade do seu povo", ${ }^{13}$ ditados por seu avô paterno, o imperador Leopoldo II. Ainda assim, a influência do romantismo de Goethe, a quem conheceu pessoalmente, resistia mesmo após sua chegada ao Rio de janeiro: "Todos são anjos de bondade, especialmente meu querido Pedro"; "Faz dois dias que estou junto do meu esposo, que não é apenas lindo, mas também bom e compreensivo", ${ }^{14}$ e eram revelados em cartas ao pai e à irmã.

No entanto, o confronto entre o romantismo e a realidade logo seria registrado. Na mesma época do casamento real, surgiu no Rio de Janeiro rumores do primeiro caso público de D. Pedro com uma francesa e o nascimento de um filho bastardo. Registros indicam que D. João VI, para resolver a situação, casou a francesa com um oficial português e envio-os à Europa. ${ }^{15}$ Mais tarde, este envolvimento foi retomado em um panfleto publicado, em 22 de maio de 1825, por um refugiado político em Buenos Aires, que dava outra versão para o desfecho: "Que pretendeis desse pai inumano, cruel e desnaturalizado, que consentiu a que por conveniência da velha corte se mandasse sufocar o terno fruto do amor que tinha tido com uma infeliz francesa." ${ }^{16}$ Nessa altura, já era prática que os casos amorosos de D. Pedro fossem assunto corrente e motivo de detração na sociedade carioca e em toda Europa.

Cartas enviadas à irmã revelam crescente descontentamento e frustração, com consequente distanciamento do ideal romântico. Em 1820, afirma que "Se hoje fosse livre, nunca mais casaria, pois (...) o santo matrimônio traz consigo muitos desgostos e aborrecimentos e o sacrifício da própria individualidade." ${ }^{17}$ Em 1821, a desilusão amorosa está instalada: "Começo a crer que se é muito mais feliz quando solteiro, pois agora só tenho preocupações e dissabores, que engulo em segredo, pois reclamar é ainda pior, infelizmente vejo que não sou amada". ${ }^{18}$ Contudo, é a partir de 1822, com o envolvimento do esposo com Domitila de Castro Canto e Melo, que a imperatriz passa a experimentar recorrentes humilhações públicas e uma melancolia, apontada como um dos fatores para sua morte prematura no final de 1826, aos 29 anos.

Em virtude da Revolução Liberal do Porto em 1820, no início de 1821, D. João VI regressou a Portugal, mas manteve D. Pedro como príncipe regente do

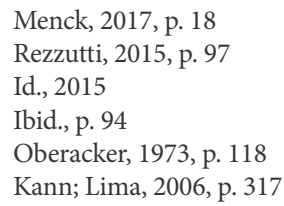


Reino do Brasil, condição a que a colônia fora elevada em 1815. Em viagem a São Paulo, em agosto de 1822, para apaziguar conflitos entre grupos políticos acerca da administração da província, foi proclamada a Independência do Brasil, em 7 de setembro, após o recebimento de cartas e despachos da imperatriz e do ministro José Bonifácio sobre os movimentos das cortes constituintes em Portugal, que desejavam reconduzir o Brasil à condição de colônia.

Nessa viagem, conheceu Domitila de Castro Canto e Melo, futura marquesa de Santos. Domitila tinha 24 anos, três filhos e estava separada do marido. Era uma mulher bonita segundo os padrões da época, foi a favorita do imperador e "reforçaria nele a imagem de um homem capaz de traficar na cama os altos interesses do Estado em troca de favores sexuais". ${ }^{19}$ Em maio de 1823, toda a família Canto e Melo mudou-se para o Rio de Janeiro e passou a viver sob as graças do imperador. Não se sabe ao certo o destino do primeiro filho do casal, concebido quando se conheceram em São Paulo, no entanto, em setembro de 1823, a amante estava grávida novamente.

Preocupado com o destino do filho, que por lei pertencia ao marido com quem Domitila legalmente seguia casada, D. Pedro interferiu no processo de divórcio e conseguiu que em poucos dias a sentença fosse lavrada. A intensidade da paixão por Domitila não foi demonstrada apenas nas cartas pessoais, as quais assinava "demonão" "fogo-foguinho" e a chamava de Titília, mas também publicamente quando tomava para si as afrontas que a paulista sofria por causa da sua condição de amante. Além disso, distribuía, por despachos e decretos, cargos, títulos e propriedades a sua protegida e a toda família Canto e Melo.

A marquesa não ficou à margem das questões políticas e tornou-se alguém a quem diplomatas e políticos recorriam quando queriam influenciar D. Pedro sobre alguma questão. O imperador não a escondia ou dissimulava, antes a mantinha próxima; para protegê-la e dar-lhe o direito de frequentar lugares exclusivos da família imperial e seu séquito, a designou dama camarista da imperatriz. $\mathrm{O}$ cargo conferia-lhe, além do direito de frequentar o palácio imperial, lugar de honra em qualquer ocasião pública. O relacionamento causava a indignação em virtude dos costumes, dos favorecimentos que prejudicavam outros e porque a imperatriz inspirava grande apreço nos cortesãos e no povo carioca.

Diante da atitude escandalosa, os diplomatas estrangeiros comunicaram às suas respectivas cortes quem era a amante oficial do imperador do Brasil, a imperatriz do seu coração, como a chamava D. Pedro. ${ }^{20} \mathrm{O}$ imperador Francisco I, quando informado pelo diplomata austríaco, barão de Mareschal, deixou

19 Gomes, 2015, p. 262

20 Rezzutti, 2015 
para a posteridade, registrado de próprio punho: "Que homem miserável é o meu genro". D. Leopoldina seguia impassível e à medida que as honrarias à amante e seus familiares se avolumavam, sua postura mais a dignificava perante todos. Apenas aos mais íntimos confidenciava o quanto as atitudes do esposo a martirizavam:

"O meu esposo se interessa somente pela maldita bruxa e à outra pode acontecer o que quiser." ${ }^{21}$;

"Aqui, infelizmente, anda tudo transtornado, pois, sinceramente falando, mulheres infames como se fosse Pompadour e Maintenon e ainda pior, visto que não têm educação alguma, (...) governam tudo torpemente."22

A humilhação pública atinge o auge no ano de 1826. Em fevereiro, D. Pedro decide visitar a Bahia acompanhado da família, dos cortesãos, dos ministros, dos militares e da amante. Durante os 24 dias de viagem, a imperatriz recolheu-se à cabine, enquanto o marido passeava pelo convés com Domitila. Mesmo durante os passeios de carruagem por Salvador, a presença da amante lhe era imposta. No mesmo ano, mandou publicar um decreto ministerial para reconhecer a paternidade da filha Isabel Maria com a marquesa. Poucos dias depois, no palacete que mandara construir, próximo à Quinta da Boa Vista, em grandiosa festa e cerimônia beija-mão celebrou o aniversário da filha e o título de duquesa de Goiás, que a colocava acima de todos os demais membros da corte.

Os jornais simpáticos ao governo imperial louvaram a atitude de D. Pedro de reconhecer a filha ilegítima, mas houve quem condenasse. Em relatório à corte, o cônsul francês Guinebaud, alerta para o que seria o sentimento do povo:

O povo clama (...) contra a fraqueza e a vilania dos conselheiros do monarca, apologistas públicos e, por escrito, de sua conduta em relação à jovem duquesa de Goiás, filha natural, fruto de duplo adultério vivo, legitimada e reconhecida, a pretexto de que os reis franceses Henrique IV e Luiz XIV tinham feito o mesmo. ${ }^{23}$

A postura de ostentar abertamente a relação incomodou a sociedade carioca. Caricaturas eram pichadas nos muros da cidade e tinham como personagens o imperador, Domitila e a imperatriz e por tema a traição. As inquietações

21 Oberacker, 2018, p. 199

22 Kann; Lima, 2006, p. 316

23 Rezzutti, 2015, p. 210 
tomaram as ruas de tal forma que na ocasião da apresentação de D. Pedro II como herdeiro do trono, a polícia recomendou que a cerimônia não fosse pública, pois havia rumores de ataque à amante e a sua família. Um resquício de prudência fez com que passasse a dar mais atenção à imperatriz, mas sem descuidar dos favores à amante, elevou seu título de viscondessa à marquesa de Santos, além de conferir outras graças a sua família. O imperador passava cada vez mais tempo no palacete da amante, onde estabelecera um escritório de despachos. Passeava em público com a amante e a filha, saia de férias com as duas enquanto a imperatriz e as princesas permaneciam em São Cristóvão. ${ }^{24} \mathrm{O}$ diplomata austríaco informou a Viena sua impressão sobre a situação:

A 29 de junho (de 1826) festejou-se D. Pedro em casa do veador da Imperatriz (...). D. Pedro, D. Leopoldina, as jovens princesas, lá passaram o dia em companhia da viscondessa de Santos, da Goiás, sua mãe, seu avô e todo o resto da família materna. A despeito dessa estranha mistura, o dia passou tão alegre e tão tranquilamente como se a poligamia estivesse legalmente estabelecida no país. ${ }^{25}$

No dia 23 de novembro de 1826, D. Pedro embarcou em direção ao sul para comandar as tropas na Guerra da Cisplatina e deixou D. Leopoldina enferma. A imperatriz faleceu no dia 11 de dezembro e colocou o Rio de Janeiro em luto. A marquesa percebeu que os títulos e a proteção de $\mathrm{D}$. Pedro não lhe conferiram o respeito do povo. Proibida de entrar no paço durante a doença da imperatriz, teve seu palacete apedrejado após a notícia da morte. O povo em comoção culpava-a pela profunda depressão que somada a complicações de um aborto ceifara a vida da benfeitora. Ao retornar do sul, D. Pedro tomou providências contra todos que tinham afrontado a amante.

Em virtude de circunstâncias políticas e da necessidade de se conseguir uma nova imperatriz, o casal fingiu rompimento e passou a se encontrar discretamente. No entanto, em novo arroubo, D. Pedro concedeu mais títulos e benesses aos familiares e à amante, o que foi amplamente noticiado por jornais na Europa. $\mathrm{Na}$ Alemanha, a divulgação dos horrores a que a imperatriz fora submetida afugentaram as pretendentes reais que, uma a uma, com desculpas, recusavam o pedido de casamento e colocavam o imperador em uma posição vexatória. Apenas em 1829, a princesa Amélia da Baviera, de origem não tão ilustre, aceitou a proposta de casamento. D. Pedro, então, parou de frequentar a casa da amante 
e exigiu que saísse do Brasil. Diante da recusa, retirou-lhe bens e a nomeação de dama do paço, além de proibir que qualquer criado do palácio a visitasse. A marquesa resistiu, mas quando ameaçou cortar-lhe a pensão, capitulou, vendeu todas as propriedades para D. Pedro e partiu para Santos com toda a família, grávida de sua última filha com o amante, com quem nunca mais se encontrou. ${ }^{26}$

O discurso do barão de Mareschal emerge de um contexto retórico permeado de elementos superlativos: a independência do Brasil tensionada pela do amor avassalador de um imperador, a melancolia de uma imperatriz e o destemor de uma amante. Nesse palco, os sujeitos escolhem lados e movidos pelas suas paixões fazem da detração um meio para atingir objetivos.

\section{A fofoca deliberativa da coesão social e do estabelecimento de identidades}

Somos seres retóricos. ${ }^{27}$ Tal afirmação projeta em nosso imaginário social ${ }^{28} \mathrm{a}$ lógica de que ser um orador é se posicionar diante de um fato. Quando partimos dessa lógica descartamos qualquer possibilidade de um discurso neutro, desse modo, assumir o papel de orador é involuntariamente "valer-se da língua como um lugar de confronto das subjetividades". ${ }^{29} \log$, somos seres retóricos porque temos crenças, valores e opiniões que emergem ao utilizarmos a palavra como instrumento revelador de nossas impressões.

Sob essa perspectiva, entendemos que o ato de fofocar é uma atitude retórica, já que a exposição de uma ideia ou opinião marca valores e crenças. Junto com a corte portuguesa, atravessaram o Atlântico costumes consolidados dentro de uma ordem social e política absolutista, que assegura direitos divinos à família real, mas também a responsabilidade de governar seus súditos. A forma como um reino é conduzido, desde as decisões mais cotidianas até as resoluções estratégicas despertam o interesse particular do povo e o geopolítico de outras potências. Logo, aqui também aportaram militares, nobres, políticos e diplomatas de diferentes reinos e impérios, com o objetivo de contribuir, firmar acordos ou apenas acompanhar a corte portuguesa e reportar a seus soberanos, por meio

\footnotetext{
26 Id., 2015

27 Ferreira, 2017

28 O imaginário social expressa-se por ideologias e utopias, e também por símbolos, alegorias, rituais e mitos. Disponível em: https:/www.acessa.com/gramsci/?page=visualizar\&id=297\#: :text=O\%20imagin\%C3\%A1rio\%20social\%20expressa\%2Dse,introdu\%C3\%A7\%C3\%A3o\%20de\%20mudan\%C3\%A7as\%20 $\% 5$ B1\%5D. Acesso em: 19/09/2020

29 Ferreira, 2017, p. 12
} 
de cartas, os movimentos do monarca. Esta era a função do barão Wenzel de Mareschal, agente diplomático da corte austríaca no Rio de Janeiro.

Não raro, entre informações econômicas e políticas, as cartas abordavam a intimidade da família real, esmaecendo as fronteiras entre o público e o privado, no que eram acompanhadas por jornais no Brasil e no exterior. A carta do barão de Mareschal, despachada para a Áustria em 13 de fevereiro de 1826, pouco depois de iniciada a viagem à Bahia, não se detinha em assuntos de Estado, mas sim em relatar ao príncipe Matternich, chanceler de Estado da Áustria, a humilhação imposta por D. Pedro a D. Leopoldina, ao levar em uma viagem oficial a amante Domitila.

A viagem da corte à Bahia deu lugar a um grande escândalo; ver o imperador fazer acompanhar-se no mesmo navio pela imperatriz, sua filha mais velha e sua amante oficial ofendeu necessariamente todo o mundo, mas o medo pessoal que a violência do caráter deste príncipe inspira fechou a boca de todos.

A senhora arquiduquesa que, naturalmente, se devia sentir a mais ferida, mostrou a este respeito a mais perfeita indiferença; a ideia da viagem a agrada mais do que ficar aqui: o único receio que ela se dignou exprimir referiu-se ao mau exemplo que isso daria à jovem princesa, criança precoce a quem nada escapa. Não sei se isto é sabedoria, filosofia prática ou despreocupação, mas a gente não se poderia conduzir com mais tato do que a arquiduquesa; todos concordam com isso e ela ganha a cada dia a opinião pública e a de seu augusto esposo.

Poucos dias antes da partida foram publicadas pasquinadas e o imperador recebeu cartas anônimas, onde o censuravam de levar a mulher só para servir de véu para a sua amante. Ficou por causa disso muito irritado e apressou-se em levar as cartas à imperatriz: esta recebeu tão estranha confidência com o seu costumado sangue-frio, dizendo-lhe que aquilo ou era falso, ou verdadeiro, que no primeiro caso não valia a pena ocupar-se com isso e no segundo seria preciso fingir que se despreza o boato para fazê-lo cair. O mais engraçado é que o sanguefrio da imperatriz enraiveceu o imperador, e ele censurou-a por não se aborrecer com ele; pôde observar-se em seguida que Sua Majestade 
aparecia constantemente em público com a senhora arquiduquesa e que ele redobrou de atenção e consideração para com ela. ${ }^{30}$

O exórdio, inicio do discurso, é o momento de estabelecer identificação com o auditório e angariar sua atenção ${ }^{31}$; o orador movimenta o pathos do auditório, com a intenção de que passe a aceitar e comungar sua opinião sobre os fatos narrados e o caráter do imperador. Vale-se da estratégia persuasiva de criar expectativa com a proposição inicial na qual se destaca a expressão grande escândalo, com o objetivo de prender a atenção do auditório e ao mesmo tempo fomentar o estado emocional que melhor se alinha ao que relatará na continuidade da carta: a indignação. Na concepção cartesiana, as paixões alteram também aquele que as provoca, neste caso, a indignação é a do próprio orador e, a seu ver, de todos que tomaram conhecimento ou testemunharam o episódio, conforme ofendeu necessariamente todo o mundo. A atitude do imperador promoveu, desde partida no Rio de Janeiro, ações de protesto e natural imaginar que escandalizasse também ao príncipe Metternich, na longínqua Áustria.

Segundo Karnal (2016), a fofoca tem como objetivo humanizar uma personagem, enfraquecê-la ou empoderá-la. É possível perceber que o orador movimenta o pathos do auditório com a intenção de enfraquecer o imperador, um homem cujo temperamento violento inspira medo e fecha a boca de todos. Censura a atitude do imperador e ao expor sua opinião articula estratégias orientadas a suscitar paixões e emoções que levem o auditório a aceitá-la. O que sentir por um homem que comete atos indignos, é violento e causa medo, senão desprezo? O auditório, portanto, na posição de juiz deve julgar as atitudes de D. Pedro.

As paixões que protagonizam este ponto do discurso é a indignação e o desprezo. De acordo com Descartes, a indignação surge diante do mal que afeta o outro e quando relacionado ao próprio indivíduo, pode dar lugar a cólera. ${ }^{32} \mathrm{~A}$ intenção do orador, portanto, é construir um discurso com potência persuasiva suficiente que faça sua indignação e desprezo viajarem até a Áustria e instalar-se no espírito do chanceler.

A busca de identificação do auditório é fundamental em qualquer discurso, porém na detração é vital. Em virtude de ser uma forma de fazer alianças, surge como um recurso para estabelecer jogos de poder. ${ }^{33} \mathrm{~A}$ conjugação estratégica do advérbio necessariamente com a expressão totalizadora todo o mundo alça o auditório à posição de ofendido e torna difícil discordar da opinião do orador, ou

\footnotetext{
Rezzutti, 2017, p. 285

Ferreira, 2017

Descartes, 2012

Karnal, 2016
} 
fugir da aliança contra o imperador. Descartes (2012) ressalta que a indignação é percebida naqueles que querem parecer virtuosos e não nos que de fato são. Nesse sentido, ao relatar e condenar o adultério, o barão de Mareschal constrói um ethos virtuoso que não compactua com indignidades.

Ao exórdio, segue a exposição dos fatos e pontos principais relacionados à causa. O narrador incita a compaixão, pois ao lembrar que a imperatriz devia se sentir a mais ferida, chama a atenção para aquilo que se passa no íntimo da arquiduquesa. Forma, com isso, uma base argumentativa para estabelecer um contraste e revelar que a imperatriz, seja por sabedoria, filosofia prática ou despreocupação, possui fortaleza de espírito e que ninguém se poderia conduzir com mais tato do que ela. O único porém, ou queixa expressada, é a preocupação em relação ao mau exemplo para a princesa, D. Maria da Glória, futura rainha de Portugal. Sobressai-se, assim, a figura da mãe abnegada, cuja preocupação central são os filhos. A forma como os argumentos são dispostos, conduzem o auditório do sentimento de compaixão ao de admiração e convergem para que seja persuadido a concordar com todos que ela ganha a cada dia a opinião pública e a de seu augusto esposo, inclusive a sua.

A paixão que se sobressai na articulação desses argumentos é a admiração. Descartes afirma que a admiração surge da surpresa, isto é, surpreendemo-nos favoravelmente com algo diferente daquilo que esperamos. Considera que é uma "súbita surpresa da alma que faz com que ela se ponha a considerar com atenção aos objetos que lhe parecem raros e extraordinários". ${ }^{34}$ Assim, é sugerido ao auditório que a postura de dignidade que a arquiduquesa ostentou diante dessa humilhação, e de tantas outras a que fora exposta, é rara e extraordinária, por isso, digna de admiração. O orador desperta, ademais, o reconhecimento, que consoante Descartes (2012), é uma espécie de amor provocado em nós, por intermédio de uma atitude daquele em quem acreditamos. É o tipo de paixão que tem muita força e provoca o desejo de retribuir. Dentro do contexto retórico da época, essa paixão somada ao amor pela imperatriz e ao ódio pela marquesa levou o povo carioca a apedrejar o palacete da favorita do imperador e a demonstrar publicamente por diferentes meios o quanto condenavam o relacionamento.

Os panfletos e publicações em jornais sobre o caso já eram recorrentes e aumentavam à medida que aumentavam as demonstrações públicas de afeto do imperador pela amante. Assim, os eventos narrados pelo diplomata, na sequência da carta, confirmam e sedimentam sua opinião e a de todos. Informar sobre a publicação de pasquinadas, textos satíricos com crítica difamatória, ${ }^{35}$ 
e o envio de cartas anônimas servem para deixar claro ao auditório o quanto a situação deteriorara. Expõe, dessa maneira, a atitude contraditória de D. Pedro em contraste com a da imperatriz, ela de sangue-frio e ele irritado. Ao mesmo tempo, testemunha mais uma vez a demonstração de sabedoria, filosofia prática ou despreocupação, retomando argumentos para sedimentar no auditório a sua opinião sobre a questão.

Para Karnal (2016), o maldizer também é um gesto político, é uma arma contra o poder. Nessa perspectiva, expor o adultério não foi somente detratar, foi também se colocar contra tudo que o imperador representava para o Estado. A detração feita pelo barão é um ato político: exaltar a atitude da imperatriz e diferenciá-la como sábia e equilibrada é uma tentativa de criar uma oposição ao imperador. Indignação, compaixão, admiração e reconhecimento alinham-se à D. Leopoldina, medo e desprezo à figura de D. Pedro. Dessa forma, o orador explicita sua posição diante da causa e sedimenta os valores e crenças que aparenta possuir.

Nesse sentido, como a sua intenção é condenar a atitude e desmoralizar o imperador, cria em seu discurso um espaço de combate, ou campo de batalha retórico, composto por um imperador adúltero, que leva a amante para viajar com a família, e uma imperatriz, sangue-frio e sábia, que lida com a ausência de caráter do marido. Persuade, Procurar, assim, persuadir o auditório a escolher o seu lado, que entre o desmoralizado e a abnegada, é o da abnegada. Para Karnal (2016), a fofoca é um processo que estigmatiza o outro e para promover esse processo os fofoqueiros precisam buscar grupos de aliança e de poder, que compartilhem da mesma opinião, para com base nessa formação a fofoca aumentar a coesão social e estabelecer identidades. Portanto, como consequência do perfil delineado pelo orador e da adesão do auditório, o imperador assume uma identidade desacreditada.

Para finalizar sua detração, o orador amplifica a ideia defendida ao reforçar as características que depõem contra o imperador: sua atitude contraditória e temperamento explosivo. A oposição sutil estabelecida entre os termos engraçado e sangue-frio diante de enraiveceu e censurou coloca para o auditório que os consortes encontram-se em campos opostos dentro do contexto: de um lado o imperador e sua amante e do outro sua esposa apoiada por toda a opinião pública, ainda que esse apoio erga-se por meio de subterfúgios ou cale-se em virtude do medo das represálias do imperador.

O final do discurso sugere uma vitória moral de D. Leopoldina e do modelo de mulher ideal que habita o imaginário social porque, embora raivoso, $\mathrm{D}$. Pedro lhe dedica mais atenção e consideração. Ademais, o uso do tratamento 
respeitoso no final da carta, indica que o orador capitula e concede o benefício da dúvida a Sua Majestade, frente a sua postura mais coerente.

Interessante notar que a estima demonstrada pelo barão Mareschal não parecia ecoar na arquiduquesa, pelo menos não a princípio. Talvez porque não quisesse seus assuntos íntimos discutidos abertamente, em 1823, solicitou ao barão austríaco von Stürmer que Mareschal fosse retirado do serviço diplomático no Rio de Janeiro: “( ... seria bom chamar de volta o barão Mareschal, que desfruta aqui de péssima reputação devido a suas opiniões intrigantes e levianas.” ${ }^{36}$

\section{Considerações finais}

Todo o processo discursivo ocorre devido às afecções psicofísicas que a argumentação compreende, ${ }^{37}$ à junção da potência patética epistêmica geradora de ação e reação ${ }^{38} \mathrm{e}$ aos processos fisiológicos decorrentes das vontades. ${ }^{39}$

Acerca dos fatos expostos, concordamos com Karnal (2016) que a fofoca é a prática que mais perdura ao longo da vida humana, pois a partir do momento em que sua rede de intrigas é estabelecida, esse discurso, subproduto da humanidade, mantém-se por anos ou até por séculos, como acontece com a fofoca histórica que envolve D. Pedro, D. Leopoldina e Domitila. A necessidade do detrator de agregar pessoas que compartilhem da mesma opinião, faz com que o discurso fofoqueiro revestido de pathos constitua-se socialmente e mantenhase no imaginário social.

É fundamental, portanto, que o detrator instigue seu auditório e estimule-o a ponto de fazer com que deixe de ser apenas auditório e passe também a ser detrator. Isso porque, além de reproduzir e propagar o discurso aderente ao teor que lhe foi informado, toma partido, muitas vezes acrescenta novos matizes, e age. Esse processo resulta em uma rede de intrigas e deixa perceber o quanto o discurso fofoqueiro em torno do adultério de D. Pedro incitou a rebelião da população e a forma de agir da corte a respeito dos assuntos pessoais da casa imperial.

A detração articula as duas vertentes patéticas e se mantém cristalizada na sociedade porque carrega uma essência conservadora, ${ }^{40}$ isto é, orienta-se pela

\footnotetext{
36 Kann; Lima, 2006, p. 419

37 Figueiredo, 2018

38 Aristóteles, 2000

39 Descartes, 2012

40 Karnal, 2016
} 
manutenção e defesa de valores e costumes aceitos pela maioria. Nesse sentido, o barão Mareschal não é julgado por produzir um discurso fofoqueiro sobre a corte, pois a sua detração imbui-se de conservadorismo, a denúncia está pautada em uma moral social. Dessa forma, a detração alicerça-se em princípios de decência e, de forma estratégica, exime o detrator da culpa de fofocar.

Concluímos, então, que a fofoca é um discurso que movimenta as paixões em suas diferentes atribuições, pois erguer-se em contextos retóricos tensionados por percepções e interesses. Também, seu contínuo pode tornar quem é auditório um orador porque se pauta nos valores e crenças com os quais o sujeito se identifica. Portanto, é um tipo de discurso, a despeito dos julgamentos que seu exercício atraia, inerente à vida humana, visto que, quando o sujeito se posiciona diante de um fato que não lhe diz respeito, torna-se o orador da fofoca.

\section{Referências}

ARISTÓTELES. Arte retórica e arte poética. 17. ed. Tradução de Antônio Pinto de Carvalho. Introdução e notas de Jean Voilquim e Jean Capelle. Rio de Janeiro: Ediouro, 2005. . Retórica das paixões. Tradução de Isis Borges da Fonseca. Prefácio, Michael Meyer. São Paulo: Martins Fontes, 2000.

AULETE, Caldas. Novíssimo Aulete: dicionário contemporâneo da língua portuguesa. Organização de Paulo Geiger. Rio de janeiro: Lexikon, 2011.

DESCARTES, R. As paixões da alma. Tradução Ciro Mioranza. São Paulo: Lafonte, 2012. FERREIRA, L. A. Leitura e persuasão: princípios de análise retórica. São

Paulo: Contexto, 2017.

FIGUEIREDO, M. F. A Retórica das paixões revisitadas. Revista Coleção Mestrado em Linguística Franca, Editora UNIFRAN, v.13, 2018, p.141-158.

GOMES, L. 1822: como um homem sábio, uma princesa triste e um escocês louco por dinheiro ajudaram dom Pedro a criar o Brasil - um país que tinha tudo para dar errado. 2 ed. São Paulo: Globo, 2015.

KANN,B.;LIMA,P.S.(org.).D. Leopoldina: cartasdeumaimperatriz.SãoPaulo:EstaçãoLiberdade, 2006. KARNAL, L. A detração: breve ensaio sobre o maldizer. Porto Alegre: Editora Unisinos, 2016

MENCK, J. T. M. D. Leopoldina, imperatriz e Maria do Brasil: obra comemorativa dos 200 anos da vinda de D. Leopoldina para o Brasil. Brasília: Câmara dos Deputados, 2017. MEYER, M. As paixões nos diálogos platônicos. In: Retórica das paixões. Tradução de Isis Borges da Fonseca. São Paulo: Martins Fontes, 2000.

OBERACKER, Jr. C. H. A imperatriz Leopoldina: sua vida e sua época. Ensaio de uma biografia. Rio de Janeiro: Conselho Nacional de Cultura, 1973.

REZZUTI, P. D. Pedro: A história não contada. O homem revelado por cartas e documentos inéditos. Rio de Janeiro: Leya, 2015. 
D. Leopoldina: A história não contada. A mulher que arquitetou a independência do Brasil. Rio de Janeiro: Leya, 2017.

TRINGALI, D. A retórica antiga e outras retóricas: a retórica como crítica literária. São Paulo: Musa, 2014.

TRUEBA ATIENZA, C. La teoría aristotélica de las emociones. Signos filosóficos, México, v. 11, n. 22, jul./dic. 2009. 